\title{
THE EFFECTS OF VOCABULARY AND GRAMMAR MASTERY TOWARD STUDENT'S READING COMPREHENSION OF GRADE X OF STATE SENIOR HIGH SCHOOL STUDENTS IN WEST JAKARTA
}

\author{
Ulfatussyarifah \\ Program of Economic Education, Faculty of Social Science, University of Indraprasta PGRI \\ Jalan Nangka No. 58C Tanjung Barat, Jagakarsa, Jakarta Selatan 12530 \\ fa.zafeera@gmail.com
}

\begin{abstract}
The objective of the research is to get empirical data concerning the effects of vocabulary and grammar mastery towards student's reading comprehension. This research is done by Kolgomorov-Smirnov method, ANOVA Table, Proportional Correct for testing the item difficulties, Biserial Coefficient and Kuder Richarson testing. Samples are taken of the achievable population were 60 students from grade eleven of social and science in section 3 and 4 at SMA Negeri 14 Jakarta. Data collection is conducted by giving test for reading comprehesion, test for vocabulary mastery, and test for grammar. The results show that there are significant effects of vocabulary mastery and grammar mastery altogether towards student's reading comprehension of X1 grade at state Senior High Schools in West Jakarta. It is proven by the score of Fo $=4,160$ dan Sig. $=0,021<0,05$. There is a significant effect of vocabulary mastery towards student's reading comprehension as it is proved by the score of to $=2,662 \mathrm{dan} \mathrm{Sig.}=0,001<0,05$. There is a significant effect of grammar mastery towards student's reading comprehension as it is proved by the score of to $=-0,222$ dan Sig. $=0,082>0,05$
\end{abstract}

Key words: vocabulary mastery, grammar mastery, reading comprehension

\begin{abstract}
ABSTRAK
Tujuan dari penelitian ini adalah untuk mendapatkan data empiris yang berkaitan dengan pengaruh penguasaan kosa kata dan tata bahasa terhadap pemahaman membaca siswa. Penelitian ini menggunakan metode Kolgomorov-Smirnov, tabel ANOVA, Proportional Correct for testing the item difficulties, Biserial coefficient dan Kuder Richarson testing. Sampel penelitian sebanyak 60 siswa kelas 11 IPS dan IPA pada sesi ke-3 dan ke-4 di SMA Negeri 14 Jakarta. Pengumpulan data dilakukan dengan memberikan tes untuk pemahaman membaca, tes untuk penguasaan kosakata, dan tes untuk penguasaan tata bahasa.. Hasil penelitian menunjukkan adanya pengaruh penguasaan kosakata dan tata bahasa secara bersama-sama terhadap pemahaman membaca. Hal ini dapat dibuktikan dengan nilai Fo = 4,160 dan Sig. = $0,021<0,05$. Terdapat pengaruh penguasaan kosakata terhadap pemahaman bacaan. Hal ini dapat dibuktikan dengan nilai to $=2,662$ dan Sig. $=0,001<0,05$. Terdapat pengaruh penguasaan tata bahasa terhadap pemahaman bacaan. Hal ini dapat dibuktikan dengan nilai to $=-0,222$ dan Sig. $=0,082>0,05$
\end{abstract}

Kata kunci: penguasaan kosakata, penguasaan tata bahasa, pemahaman membaca 


\section{INTRODUCTION}

The mastery of large vocabulary has an important role in understanding sentences/texts, because vocabulary can help the learners to grasp the meanings of the utterances given. Mastering vocabulary is the way for the teachers to improve their student's reading comprehension in spoof text. Many students will understand more if they have already known vocabulary because they really help the students to comprehend the reading text. This is the reason why students are demanded to master the vocabulary before they comprehend the spoof text.

In the world of education, teachers should have strategies or ways to teach vocabulary effectively. Good method of teaching will always become the major effect to students' vocabulary mastery. With it, the learners might probably improve their reading comprehension. However there are some teachers who teach the reading ineffectively. They need long time to explain the meaning of words and the phrases. A lot of time is wasted when they explain the synonym/antonym of words or similarities and differences of grammar. The learners cannot understand easily what the teacher explains because the teacher forces the learners to understand $\mathrm{him} / \mathrm{her}$. If that happens all the time, the learners would not be able to improve their reading comprehension.

Vocabulary is one of the language aspects which should be learnt. Learning vocabulary is important because we are able to speak, write, and listen nicely we have to know vocabulary first. A person said to "know" a word if they can recognize its meaning when they see it. It means that in learning vocabulary we have to know the meaning of it and also understand and can use it in sentence context. Vocabulary is the score component of language proficiency and provides much of the basis for how well learners speak, listen, read, and write. Vocabulary is one of the language components that can affect macro skills. Vocabulary is referred to as: 1) stock of words used by person, classes of people, profession, etc; and 2) a collection or list of words, usually in alphabetical order and defined. Vocabulary (lexicon) is a component of language that contains all the information about the meaning and use of the word.

Vocabulary is a set of lexeme, including single words, compound words and idioms. The terms of vocabulary, lexis and lexicon are synonymous. Vocabulary is the total number of words in a language; all the words known to a person or used in a particular book, subject, etc; a list of words with their meaning, especially one that accompanies a textbook (Hornby, 1995). Vocabulary is a list of target language words. Those definitions show that vocabulary is the first element that the English learners should learn in order to master English well besides the other English components and skills.

The vocabulary of language always changes and grows. As life becomes more complex, people device or borrow new words to describe man's activities. No one knows the exact numbers of words in the English vocabulary today. It means that vocabulary is the core component of language proficiency that consists of a set of lexeme, including single words, compound words, idioms; provides much of the basis for how well learners speak, read, listen, and write; and has similarities with the term "lexis" and "lexicon".

In language learning, vocabulary takes place in building the language proficiency. The objective of vocabulary mastery is to make students have a good language proficiency in the language 
skills. It depends on the quality and quantity of the vocabulary that they have mastered. The richer the vocabulary that can be mastered by the students, they will get the better skill that can be reached in using language. Talking about vocabulary, Elfrieda, Hiebert and Kamil (2005:2-3) define vocabulary as "Knowledge of words and words meaning in both oral and print language and in productive and receptive forms". Word meaning is also governed by metaphors and idioms, e.g., the word refers to the noise of snake and to someone's threat to others. In collocation, a word goes with each other, such as, headache, earache, and soon. In addition, style and register is applied by differentiating the language to be used by someone either in a formal or informal context. Moreover, word formation may also create word meaning is seeing them on their grammatical contexts. It means that we look at how the suffixes and the prefixes work (im-, or, in-) such as in the words imperfect and perfect, inappropriate and appropriate.

Vocabulary mastery is one thing that can be done through various sources; it could be from the source of learning and not learning. Mastery of one can be affect another person about what he thinks and then keeps it in mind so that it can be used at any time. In other words, a person is required to be able to master the vocabulary of a language well. Meanwhile, the vocabulary can be generally defined as the number of words of a person. Vocabulary is controlled by a person or group of people in the same environment.

Vocabulary is one of the language aspects which should be learnt. Vocabulary is one basic component to be mastered. It is reasonably, remembering that the four language skills need knowledge of words because they will get nothing without vocabulary. The larger students master vocabulary the better that perform their language. By too limited vocabulary, the students will find difficulties in mastering reading and other skills vocabulary mastery means the students have the ability in understanding and using the vocabulary. Vocabulary is knowledge involve knowing the meanings of words and therefore the purpose of a vocabulary test in to find out whether the learners can match each word with a synonym, a dictionary - tape definition, or an equivalent word in their own language (Eastwood, 2000:16).

Vocabulary is a core component of language proficiency and provides much of the basis for how well learners speak, listen, read, and write. Without an extensive vocabulary and strategies for acquiring new vocabulary, learners often achieve less than their potential and may be discourage from making use of language learning opportunities around them such as listening to the radio, listening to the native speakers, using the language in different context, reading, or watching television.

Learning vocabulary should also be connected in the grammar lesson as students write texts need the elements of both aspects. In fact, grammar is "multidimensional" and has multi meanings. It is generally thought to be a set of rules for choosing words and putting words together to make sense. Every language has grammar. It has been held that if a language is a building, the words. Grammar is the branch of linguistics that studies how language sentences are formed. It is the rule how to make sentences in English correctly. This statement is supported by Thornburry (2002:1-2) who says, "Grammar is a part study of what forms (or structure) are possible in language. Traditionally, grammar has been concerned almost exclusively with analysis at the level of 
the sentences.

Grammar also can be defined as a description of the way a language works. In other words, grammar is the set of structural rules that governs the composition of clauses, phrases, and words in any given natural language. The term refers also to the study of such rules, and this field includes morphology, syntax, and phonology, often complemented by phonetics, semantics, and pragmatics. Grammar of language is the description of the ways in which words can change their forms and can combine into sentences in that language.

Understanding grammar will make the students more logically. Grammar allows the students to be a good writer, listener, thinker, reader and communicator at the same time. In addition, incorrect or improper grammar can change the meaning of what you are trying to say or, at least make your meaning hard to do cipher and incorrect grammar says something about you and the quality of your thinking. Once the students have mastered English grammar, they will be able to communicate with anyone and everyone. The more grammar rules the students have mastered, the clearer communication will be. The students have to grasp a good grammar and know how to explain it at the same time. Having a good quality in mastering grammar make the students feel more confident to speak or to write in English. It is also included in reading comprehension, the more grammar students have mastered to produce good sentence, the better their score in answering the essay form.

Reading is one of important activities that the learners need to identify written or printed material. However, when students read an English text, it will be a little difficult because they must know the meaning of words in the text. The difficulties in reading English is that reading is thinking the meaning while your eyes see the world. According to the definition, reading is thinking process to find the meaning when students read every word in text. Generally, reading is a means of communication. It is a specific means of communication with friends and relatives who are around.

Reading also can be a way of sharing another person's insights, joys, sorrow, and so on. Reading is an interactive process. This means that when we converse with people, it is obvious that we depend on one another; each participant relies on certain unspoken rules that the others will follow. The most essential point in reading an English text is to know the meaning from the words in the text. It can help the students to know the writer's idea or point of view.

Efficient reading consists of clearly identifying the purpose in reading something. By doing so, you know what you're looking for and can weed out potential distracting information. Whenever you are teaching a reading technique, make sure students know their purpose in reading something. Reading comprehension helps a reader to comprehend the text that he/she reads. Reading comprehension is understanding written text means extracting the required information from it as efficiently as possible, further, locating the relevant advertisement on the board and understanding the new information contain in the article demonstrates the reading purpose in each has been successfully fulfilled. Moreover, reading comprehension is assumed as "the process of understanding the message that the author is trying to convey. Very simply, it is making meaning from the text at 
hand. Reading comprehension is the act of understanding what you are reading. Comprehension, furthermore, is a complex intellectual process involving a number of abilities. The two major abilities involve the word meanings and reasoning with verbal concepts. This means that reading comprehension is a process of constructing meaning from a text and an active thinking process.

Several previous studies of the effects of grammar translation method and vocabulary mastery towards student's reading comprehension have been conducted. One of them was done by Dr. Ali Jahangard, Dr. Ahmad Moinzadeh and Akbar Karimi M.A entitled "The Effect of Grammar vs. Vocabulary Pre-teaching on EFL Learners' Reading Comprehension: A Schema-Theoretic View of Reading". This study was designed to investigate the effect of grammar and vocabulary pre teaching, as two types of pre-reading activities, on the Iranian EFL learners' reading comprehension from a schematheoretic perspective. The sample consisted of 90 female students studying at pre-university centers of Isfahan. The subjects were randomly divided into three equal-in-number groups. They participated in a test of overall language proficiency, and the results indicated that they were linguistically homogeneous. Then, the three groups were exposed to different treatments. Group a received grammar pre-teaching, whereas group B received vocabulary pre-teaching. The subject in group C (the control group), however, received no pre-teaching. The subjects in each one of the experimental groups took reading comprehension posttests. The results showed no significant difference among the three groups though the vocabulary group performed slightly better than the other two groups, and the performance of the grammar group was seemingly worse than the control group. The findings of the study are discussed in detail with reference to the schema-theoretic view of reading.

Another study was done by Sofia Permatasari, Cucu Sutarsyah, and Muhammad Sukirlan by the title "The Correlation between Students' Vocabulary and Grammar Mastery and Reading Comprehension. The purpose of this study is to find out whether there is significant correlation between students' vocabulary and grammar mastery and their achievement in reading comprehension. This was quantitative research applied ex post facto designs. The population of this study was the second grade students of SMAN 1 Tumijajar. The researchers used sample consists of 35 students. The instrument of this research was in the form of vocabulary and grammar mastery test and reading comprehension test. The data collected were analyzed by using Pearson Product Moment Correlation in SPSS 16.0. The result showed that $r$ of students' vocabulary mastery and reading comprehension, grammar mastery and students' reading comprehension, and students' vocabulary and grammar mastery and their achievement in reading comprehension were $.839, .726$, and .870 . Therefore, it can be concluded that there is correlation between students' vocabulary and grammar mastery and their achievement in reading comprehension. The higher students' master vocabulary and grammar, the higher students' get achievement reading comprehension.

\section{METHOD}

The method used in this research is survey. From the result of survey data was analyzed using double linear regression. This method pointed out the determination of information about 
variable not about the information of individual. The application of this method is performed through tested instruments to the students by using a multiple choice test for the vocabulary mastery, grammar mastery and reading comprehension. So the relationship design that becomes the conclusion in this research is as follows:

\section{Research Design}

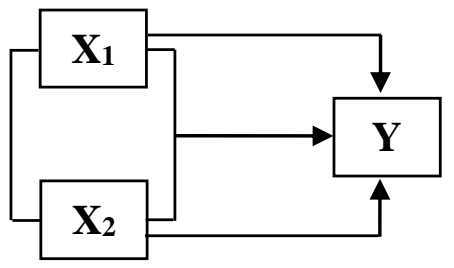

Note:

$\mathrm{X}_{1}=$ independent variable: a symbol of vocabulary mastery

$\mathrm{X}_{2}=$ independent variable: a symbol of grammar mastery

$\mathrm{Y}=$ dependent variable: symbol of reading comprehension

1. Variable XI (Student's Vocabulary Mastery)

a. Conceptual Definition

Mastery can be defined as the ability to understand in applying a concrete form. Understanding in this matter is related to the theory or the existing rules, while applying can be understood as a manifestation of the theory to a tangible form. Thus, vocabulary mastery means the ability to choose word by word when reading a text.

b. Operational Definition

Achievement of vocabulary mastery is the absorption especially better understanding, comprehension, and vocabulary. The researcher presents the score of vocabulary by using a vocabulary test in multiple choice forms.
2. Variable X2 (Student's Grammar Mastery)

a. Conceptual Definition

Grammar mastery is the ability to arrange the sentence in good composition. It is conducted with the rules of English grammar.

b. Operational Definition

Achievement of grammar mastery is absorption especially better understanding, comprehension, and grammar. The researcher presents score of grammar by using a grammar test in multiple choice forms.

3. Variable Y (Student's Reading Comprehension)

a. Conceptual Definition

Reading comprehension is the ability to understand a written communication. The essence of reading then, is comprehension-the understanding of the black marks on paper.

b. Operational Definition

To know student's reading comprehension, the researcher presents score of reading comprehension by using a reading comprehension test in multiple choice forms.

\section{Statistical Hypothesis}

1. Hypothesis 1

$\mathrm{H} 0: \beta 1=\beta 2=0 \rightarrow \quad$ there are no effects of vocabulary mastery and grammar mastery towards reading comprehension.

$\mathrm{H} 1: \beta 1 \neq 0, \beta 2=0 \rightarrow$ there are effects of vocabulary mastery and grammar mastery towards reading comprehension

2. Hypothesis 2

$\mathrm{H} 0: \beta 1=0 \rightarrow \quad$ there is no effect of vocabulary mastery towards reading comprehension

$\mathrm{H} 1: \beta 1 \neq 0 \rightarrow$ there is an effect of vocabulary mastery towards 
reading comprehension

3. Hypothesis 3

$\mathrm{H} 0: \beta 2=0 \rightarrow \quad$ there is no effect of grammar mastery towards reading comprehension

$\mathrm{H} 1: \beta 2 \neq 0 \rightarrow$ there is an effect of grammar mastery towards reading comprehension

\section{RESULTS AND DISCUSSION}

\section{Normality Test}

Normality test is used to test and determine whether the data normal or not so that tobserved, partial correlation, multiplecorrelation, single-regression and multiple regression can be analyzed. In this survey research, there are 60 students to be the respondents. However, Sudjana (1996) and Hadi (1986:70) point out that a total number of respondents are same or more than 30 or ten times of the total variables. It means that the total respondents of this survey research answer the requirement. There are 3 variables namely: grammar mastery test, vocabulary mastery test, and reading comprehension test are in the normal distribution.

To test the normality test of the data distribution by using SPSS version 21.0 for windows. It can be obtained by normality test. Each sample data will be tested its normality through hypothesis as follows: normally

$\mathrm{H}_{\mathrm{o}}$ : sample data is distributed

$\mathrm{H}_{1}$ : sample data is not distributed normally

According to the criteria of that program, the set of data will be classified as normal if $\mathrm{p}$ value (significance/Sig) above than 0.05 . As the consequence, $\mathrm{H}_{\mathrm{o}}$ is accepted, which means sample data is distributed normally. The score of $p$ value is the number in Asymp. Sig (2tailed) coloumn of output from the calculation through SPSS version 21.0 for Windows. From the results, the Sig value for vocabulary mastery, grammar mastery and reading comprehension are stated consecutively by $0,565,0.133$ and 0.076. As the consequence, $H_{0}$ is accepted. So we can conclude that all data are already distributed normally since the values of significance are all higher than 0.05 .

\section{Linearity Test}

The linearity test is an assumption in the regression analysis. It means that the regression line between $\mathrm{X}$ and $\mathrm{Y}$ forming whether or not in the linear line. If the line is not linear, it cannot be automatically continued to the next step. The test of linearity in this survey research will follow the hypothesis as follows:

$\mathrm{H}_{\mathrm{o}}$ : the regression line between variable $\mathrm{X}$ and variable $\mathrm{Y}$ is linear

$\mathrm{H}_{1}$ : the regression line between variable $\mathrm{X}$ and variable $\mathrm{Y}$ is not linear

The linearity test of the regression line can be calculated by calculated by using SPSS version 21 for Windows. According to the normal assumption, the set of data will be classified as linear in regression line if Sig. value is higher than 0.05 which means the $\mathrm{H}_{\mathrm{o}}$ is accepted and automatically $\mathrm{H}_{1}$ is rejected. The Sig value is number which is located in Sig. coloumn of Deviation from Linearity in ANOVA table as the result of calculation of linearity test through SPSS version 21 for Windows. 
a. Linearity of Regression Line the effect of Vocabulary Mastery $\left(\mathrm{X}_{1}\right)$ towards Student's Reading Comprehension (Y) The linearity test result of regression line the effect of vocabulary mastery $\left(\mathrm{X}_{1}\right)$ towards student's reading comprehension $(\mathrm{Y})$ is stated in the following table:

Table 1

Linearity Test Result of Regression Line the Effect of Vocabulary Mastery $\left(\mathrm{X}_{1}\right)$ and Reading Comprehension (Y)

ANOVA Table

\begin{tabular}{|c|c|c|c|c|c|c|c|}
\hline & & & $\begin{array}{c}\text { Sum of } \\
\text { Squares }\end{array}$ & $\overline{\mathrm{df}}$ & $\begin{array}{c}\text { Mean } \\
\text { Square }\end{array}$ & $\mathrm{F}$ & Sig. \\
\hline \multirow{7}{*}{$\begin{array}{l}\text { Reading } \\
\text { Comprehension * } \\
\text { Vocabulary Mastery }\end{array}$} & \multirow{5}{*}{$\begin{array}{l}\text { Between } \\
\text { Groups }\end{array}$} & (Combined) & 520,833 & 13 & 40,064 & 1,172 & ,329 \\
\hline & & Linearity & 265,027 & 1 & 265,027 & 7,753 & ,008 \\
\hline & & Deviation & 255,806 & 12 & 21,317 &, 624 & ,811 \\
\hline & & from & & & & & \\
\hline & & Linearity & & & & & \\
\hline & \multicolumn{2}{|c|}{ Within Groups } & 1572,500 & 46 & 34,185 & & \\
\hline & \multicolumn{2}{|l|}{ Total } & 2093,333 & 59 & & & \\
\hline
\end{tabular}

Based on the table 1 above, the Sig value from Deviation from Linearity coloumn in 0.811 . It means that the value is higher than 0.05 . as the consequence, $\mathrm{H}_{\mathrm{o}}$ is accepted and automatically $\mathrm{H}_{1}$ is rejected. In other words, we can say that the regression line which indicates the effect of vocabulary mastery $\left(\mathrm{X}_{1}\right)$ towards

Table 2

reading comprehension $(\mathrm{Y})$ is linear.

b. Linearity of Regression Line the Effect of Grammar Mastery (X2) towards Student's Reading Comprehension (Y)

The linearity test result of regression line the effect of grammar mastery (X2) towards student's reading comprehension $(\mathrm{Y})$ is stated in the following table:

Linearity Test Result of Regression Line the Effect of Grammar Mastery (X2) and

Student's Reading Comprehension (Y)

ANOVA Table

\begin{tabular}{|c|c|c|c|c|c|c|c|}
\hline & & & $\begin{array}{c}\text { Sum of } \\
\text { Squares }\end{array}$ & $\mathrm{df}$ & $\begin{array}{l}\text { Mean } \\
\text { Square }\end{array}$ & $\mathrm{F}$ & Sig. \\
\hline \multirow{7}{*}{$\begin{array}{l}\text { Reading } \\
\text { Comprehension * } \\
\text { Grammar Mastery }\end{array}$} & \multirow{5}{*}{$\begin{array}{l}\text { Between } \\
\text { Groups }\end{array}$} & (Combined) & 580,833 & 15 & 38,722 & \multirow{5}{*}{$\begin{array}{l}1,126 \\
1,152 \\
1,125\end{array}$} & \multirow{5}{*}{$\begin{array}{l}363 \\
, 289 \\
365\end{array}$} \\
\hline & & Linearity & 39,590 & 1 & 39,590 & & \\
\hline & & Deviation & 541,244 & 14 & 38,660 & & \\
\hline & & from & & & & & \\
\hline & & Linearity & & & & & \\
\hline & \multicolumn{2}{|c|}{ Within Groups } & 1512,500 & 44 & 34,375 & & \\
\hline & \multicolumn{2}{|l|}{ Total } & 2093,333 & 59 & & & \\
\hline
\end{tabular}


Based on the table 4.4 above, the Sig. value from Deviation from Linearity column is 0.365 . It means that that the value is higher than 0.05 . As the consequence, $\mathrm{H}_{\mathrm{o}}$ is accepted and automatically $\mathrm{H}_{1}$ is rejected. In other words, we can say that the regression line which indicates the effect of grammar mastery (X2) toward student's reading comprehension (Y) is linear. To sum up, regression line both vocabulary mastery and grammar mastery toward student's reading comprehension which illustrates the effects are stated in the linear position according to SPSS version 21 for Windows computation.

3. Testing of Hypotheses

Testing of hypotheses is done based on statistical hypotheses. The recapitulation of the entire test can be seen in the set of following tables:

Table 3

The Recapitulations Result of Multiple Correlation Coefficients of the Effects

of Vocabulary Mastery and Grammar Mastery

toward Student's Reading Comprehension

Model Summary ${ }^{\mathrm{b}}$

\begin{tabular}{|l|c|r|r|c|r|r|r|r|r|}
\hline Model & $\mathrm{R}$ & $\mathrm{R}$ \\
Square & $\begin{array}{c}\text { Adjusted } \\
\mathrm{R} \\
\text { Square }\end{array}$ & $\begin{array}{c}\text { Std. } \\
\text { Error of } \\
\text { the } \\
\text { Estimate }\end{array}$ & $\begin{array}{c}\mathrm{R} \\
\text { Square } \\
\text { Change }\end{array}$ & $\begin{array}{c}\mathrm{F} \\
\text { Change }\end{array}$ & df1 & df2 & $\begin{array}{c}\text { Sig. F } \\
\text { Change }\end{array}$ \\
\hline 1 &, $357^{\mathrm{a}}$ &, 127 &, 097 & 5,66108 &, 127 & 4,160 & 2 & 57 &, 021 \\
\hline
\end{tabular}

a. Predictors: (Constant), Grammar Mastery, Vocabulary Mastery

b. Dependent Variable: Reading Comprehension

Table 4

The Recapitulation Result for Regression Coefficient Significant Test of the Effect of

Vocabulary Mastery (X1) and Grammar Mastery (X2)

toward Student's Reading Comprehension (Y)

ANOVA $^{\mathrm{a}}$

\begin{tabular}{|rl|r|r|r|r|r|}
\hline \multicolumn{1}{|l|}{ Model } & \multicolumn{1}{c|}{$\begin{array}{c}\text { Sum of } \\
\end{array}$} & Squares & Df & Mean Square & F & \multicolumn{1}{c|}{ Sig. } \\
\hline \multirow{2}{*}{1} & Regression & 266,607 & 2 & 133,304 & 4,160 &, $021^{\mathrm{b}}$ \\
& Residual & 1826,726 & 57 & 32,048 & & \\
& Total & 2093,333 & 59 & & & \\
\hline
\end{tabular}

a. Dependent Variable: Reading Comprehension

b. Predictors: (Constant), Grammar Mastery, Vocabulary Mastery 
Table 5

The Recapitulation Result for Linear Regression Equality Test of The Effects of Vocabulary Mastery $\left(\mathrm{X}_{1}\right)$ and Grammar Mastery (X2) towards Student's Reading Comprehension (Y)

Coefficients $^{\mathrm{a}}$

\begin{tabular}{|c|c|c|c|c|c|c|c|c|c|c|}
\hline \multirow[t]{2}{*}{ Model } & \multicolumn{2}{|c|}{$\begin{array}{l}\text { Unstandardized } \\
\text { Coefficients }\end{array}$} & \multirow{2}{*}{\begin{tabular}{|c|}
$\begin{array}{c}\text { Standar- } \\
\text { dized } \\
\text { Coeffici } \\
\text { ents }\end{array}$ \\
Beta
\end{tabular}} & \multirow[t]{2}{*}{$\mathrm{t}$} & \multirow[t]{2}{*}{ Sig. } & \multicolumn{3}{|c|}{ Correlations } & \multicolumn{2}{|c|}{$\begin{array}{l}\text { Collinearity } \\
\text { Statistics }\end{array}$} \\
\hline & $\mathrm{B}$ & $\begin{array}{l}\text { Std. } \\
\text { Error }\end{array}$ & & & & $\begin{array}{l}\text { Zero- } \\
\text { order }\end{array}$ & $\begin{array}{l}\text { Par } \\
\text { tial }\end{array}$ & $\begin{array}{c}\text { Par } \\
\mathrm{t}\end{array}$ & $\begin{array}{c}\text { Toleran } \\
\text { ce }\end{array}$ & VIF \\
\hline (Constant) & $\begin{array}{r}70,25 \\
6\end{array}$ & $\overline{3,547}$ & & $\begin{array}{r}19,80 \\
8\end{array}$ &, 000 & & & & & \\
\hline $\begin{array}{l}\text { Vocabular } \\
1 \text { y Mastery }\end{array}$ & ,141 & 053 & ,370 & 2,662 & ,010 & ,356 & $\begin{array}{r}, 33 \\
2\end{array}$ & $\begin{array}{r}32 \\
9\end{array}$ & ,793 & 1,26 \\
\hline $\begin{array}{l}\text { Grammar } \\
\text { Mastery }\end{array}$ &,- 014 & ,064 &,- 031 &,- 222 & ,825 & ,138 & $\begin{array}{r}- \\
02 \\
9\end{array}$ & $\begin{array}{r}- \\
02 \\
7\end{array}$ & ,793 & $\begin{array}{r}1,26 \\
1\end{array}$ \\
\hline
\end{tabular}

a. Dependent Variable: Reading Comprehension

Based on the three tables above, the testing of hypothesis is formulated both statistically and verbally in the following:

1. The Effects of Vocabulary Mastery (X1) and Grammar Mastery (X2) towards Student's Reading Comprehension (Y)

$\mathrm{H}_{\mathrm{o}}: \beta_{1}=\beta 2=0$

$\mathrm{H}_{1}: \beta_{1} \neq 0 \beta 2 \neq 0$

Explanation:

$\mathrm{H}_{0}$ : There is no effect of vocabulary mastery and grammar mastery altogether towards student's reading comprehension

$\mathrm{H}_{1}$ : There are effects of vocabulary mastery and grammar mastery altogether towards student's reading comprehension.

Refer to table above, we can see that the coefficient correlation of the effects of independent variables vocabulary mastery (X1) and grammar mastery (X2) altogether towards dependent variable the student's reading comprehension (Y) is 0,357. It indicates that among variables have very strong effects. Furthermore, according to the recapitulation above, we may get that coefficient correlation value is significant. In other words, there is a significant bound effect among the independent variables: vocabulary mastery (X1) and grammar mastery (X2) altogether towards the dependent variable: student's reading comprehension (Y). Meanwhile, the coefficient of determination vocabulary mastery and grammar mastery variables contribute to reading comprehension variable is 0.127 . It indicates that the contribution of independent variables: vocabulary mastery and grammar mastery altogether towards the dependent variable: student's reading comprehension is about $12 \%$ and the test for about $88 \%$ is determined by the other factors.

According to regression analysis which is used to test hypothesis, we may set the 
regression line equality that represents the effect of independent variables: vocabulary mastery $\left(\mathrm{X}_{1}\right)$ and grammar mastery $\left(\mathrm{X}_{2}\right)$ towards the dependent variable: student's reding comprehension $(\mathrm{Y})$ in the following equation:

Where:

$\hat{\mathrm{Y}}=$ dependent variable

$\mathrm{X}=$ independent variables

Grammar mastery $\left(\mathrm{X}_{1}\right)$ altogether towards the dependent variable: student's reading comprehension (Y) as we know, Sig value is a number which is stated in Sig column on Table 4.6, while Fobserved is a number which is stated in F column on table 4.6 as well. The value for Ftable is the value of $\mathrm{F}$ on the distribution table in 5\% real degree, with the numerator degree $(\mathrm{k})=2$ and the denominator degree $(n-k-1)=57$, where $n$ is the total number of respondent, while $\mathrm{k}$ is the total number of independent variables.

Based on table 4.6 above, we can see that Sig value is stated by 0,000 and Fobserved is stated by 79.659 , while Ftable is stated by 3.16. Since the Sig value is less than 0.05 and Fobserved is higher than Ftable as the consequence $\mathrm{H}_{0}$ is rejected and automatically the $\mathrm{H}_{1}$ is accepted. It means that coefficient of regression is significant. In general, we may say that there is a significant effect of independent variables: vocabulary mastery $\left(\mathrm{X}_{1}\right)$ and grammar mastery (X2) altogether towards the dependent variable student's reading comprehension (Y).

From the recapitulation of the test result either correlation or regression we can draw a conclusion that there are effects of vocabulary mastery $\left(\mathrm{X}_{1}\right)$ and grammar mastery (X2) altogether towards student's reading comprehension $(\mathrm{Y})$.

2. The Effect of Vocabulary Mastery $\left(\mathrm{X}_{1}\right)$ towards Student's Reading Comprehension (Y)

$\mathrm{H}_{\mathrm{o}}: \beta_{1}=0$

$\mathrm{H}_{1}: \beta_{1} \neq 0$

Explanation:

$\mathrm{H}_{0}$ : there is no significant effect of vocabulary mastery towards student's reading comprehension

$\mathrm{H}_{1}$ : there is a significant effect of vocabulary mastery towards student's reading comprehension

To test the hypothesis above, we can simply see from the numbers which are stated in t column or Sig column in the row of vocabulary mastery on the table. According to general assumption, the significance of regression is if tobserved is higher than ttable or Sig value is less than 0.05 . It brings consequence that $\mathrm{H}_{0}$ is rejected and $\mathrm{H}_{1}$ is automatically accepted. It means that there is a significant effect of the independent variable $X_{1}$ toward the dependent variable $\mathrm{Y}$. Sig value is the number which is stated in Sig. column for the row of vocabulary mastery (variable $\mathrm{X}_{1}$ ) on the table. Meanwhile tobserved value is the number which is stated in $\mathrm{t}$ column for grammar mastery (variable $\mathrm{X}_{1}$ ) on the table as well. For the value of $t$-table for $5 \%$ real degree and degree of freedom $(\mathrm{df}$ $=\mathrm{n}-2$ ) is 58 , where $\mathrm{n}$ is the total number of respondents.

Refer to table above, we can see that Sig value is stated by 0,000 and tobserved is stated by 6.805 , while ttable is stated by 2.00 . Since Sig value is less than 0.05 and tobserved is higher than ttable, it 
brings consequence that $\mathrm{H}_{\mathrm{o}}$ is rejected and automatically $\mathrm{H}_{1}$ is accepted. It means that there is a significant effect of independent variable $\mathrm{X}_{1}$ (vocabulary mastery) towards the dependent variable $\mathrm{Y}$ (student's reading comprehension).

From the tabulation of correlation test, regression test and linear model above, we can conclude that there is a significant effect of independent variable $\mathrm{X}_{1}$ (vocabulary mastery) towards the dependent variable Y (student's reading comprehension)

3. The Effect of Grammar Mastery $\left(\mathrm{X}_{1}\right)$ towards Student's Reading Comprehension (Y)

$\mathrm{H}_{\mathrm{o}}: \beta 2=0$

$\mathrm{H}_{1}: \beta 2 \neq 0$

Explanation:

$\mathrm{H}_{0}$ : there is no significant effect of grammar mastery towards student's reading comprehension

$\mathrm{H}_{1}$ : there is a significant effect of grammar mastery towards student's reading comprehension

To test hypothesis above, we can simply see from the numbers which are stated in t column or Sig column in the row of grammar mastery on the table. According to general assumption, the significance of regression is if tobserved is higher than ttable or Sig value is less than 0,05 , it brings consequence that $\mathrm{H}_{\mathrm{o}}$ is rejected and $\mathrm{H}_{1}$ is automatically accepted. It means that there is a significant effect of the independent variable $X_{1}$ towards the dependent variable Y. Sig value is the number which is stated in Sig column for the row of grammar mastery (Variable $\mathrm{X}_{2}$ ) on the table. Meanwhile tobserved value is the number which is stated in $t$ column for grammar mastery (Variable $\mathrm{X}_{1}$ ) on table as well for the value of ttable for 5\% real degree and degree of freedom ( $\mathrm{df}$ $=\mathrm{n}-2)$ is 58 , where $\mathrm{n}$ is the total number of respondents.

Refer to table above, we can see that Sig value in stated by 0,009 and tobserved is stated by 2.00 . Since Sig value is less than 0.05 and tobserved is higher than ttable, it brings consequence that $\mathrm{H}_{\mathrm{o}}$ is rejected and automatically $\mathrm{H}_{1}$ is accepted. It means that there is a significant effect of independent variable X2 (grammar mastery) towards the dependent variable $\mathrm{Y}$ (student's reading comprehension).

From the tabulation of correlation test, regression test and linear model above, we can conclude that there is a significant effect of independent variable X2 (grammar mastery) towards the dependent variable Y(student's reading comprehension).

This research is concluded to find out the effect of vocabulary mastery and grammar mastery altogether towards the student's reading comprehension. Overall the interpretation is stated as follows:

1. The Effect of Vocabulary ND Grammar Mastery altogether towards The Student's Reading Comprehension

From data description gained after analyzing the correlation, we may get the coefficient of correlation. Meanwhile, from the regression analysis we may get the linear regression as follow: $\hat{\mathrm{Y}}=$ $11.411+0.464 \mathrm{X}_{2}$. According to the constant number stated by 11.411 , it shows that at the lowest level of vocabulary mastery and grammar mastery, it will be difficult for a student to achieve the good reading comprehension. While scores of 
regression coefficient stated consecutively by 0.751 and 0.349 , they show us about the positive correlation of independent variables $\mathrm{X}_{1}$ (vocabulary mastery) $\mathrm{X} 2$ (grammar mastery) altogether towards dependent variable $\mathrm{Y}$ (student's reading comprehension). They also show that each score increment for vocabulary mastery, will affect the level of reading comprehension as many as 0.751 and each score increment for grammar mastery level, will affect the level of reading comprehension as many as 0.349 .

Having tabulated the linear regression by using SPSS version 16.0 for Windows, we attain that the regression line is linear. And from the calculation by using the same program, we also attain that the coefficient of regression is significant as well. It means that there is positive correlation among the independent variables: $\mathrm{X}_{1}$ (vocabulary mastery) and $\mathrm{X} 2$ (grammar mastery) altogether towards the dependent variable $\mathrm{Y}$ student's reading comprehension.

Refer to the theoretical review on chapter II, vocabulary mastery is process to comprehend English vocabulary learned from the messages communicated. The mastery of vocabulary can be classified into: (1) The vocabulary mastery as the result of learning and the vocabulary as the effect of environment; and (2) vocabulary mastery acquired through the environment including family, social interaction and so on. Development of vocabulary starts from childhood and continues to long life.

Meanwhile, grammar mastery is the student's ability in finding out the words meaning in a sentence or paragraph in the context, functional words, idioms, and also phrasal verbs. The grammar mastery can be enriched by giving a set of drilling to a student about words implementation. Labeling a word to a picture, describing someone or something, finding the synonyms or antonyms from the text or passage.

2. The Effect of Vocabulary Mastery towards Student's Reading Comprehension

From the hypothesis test, it is attained that Sig value is 0,029 and tobserved is 6.805 , while ttable is 2.00. Because Sig $<0.05$ and tobserved $>$ ttable as the consequence $\mathrm{H}_{0}$ is rejected which means there is a significant effect of independent variable $\mathrm{X}_{1}$ (vocabulary mastery) towards the dependent variable Y (student's reading comprehension).

Vocabulary mastery can be defined as anumber of vocabulary (words) in a language which contains information about its meaning, form and usage in context of communication. It is the basuc knowledge that students should master first before mastering English.

Reading is a set of skills that involves making senses and deriving meaning from printed word. In order to read, we must be able to decode (sound out) the printed words and also comprehend what we read. Reading comprehension is defined as the level of understanding comes from the interaction between the words that are written and how they trigger knowledge outside the text. Proficient reading depends on the ability to recognize words quickly and effortlessly. If word recognition is difficult, student uses too much of 
their processing capacity to read individual words, which interferes with their ability to comprehend what is read.

It can be assumed that the higher level of vocabulary mastery possessed by the students especially correlated to reading comprehension. It may happen because vocabulary is also important in languiage learning which has to be mastered by students to develop the language skills, especially reading. In other words, student should have adequate vocabulary if they want to convey the meaning of reading material as well.

\section{The Effect of Grammar Mastery towards Student's Reading Comprehension}

From the hypothesis test, it is attained that Sig. value is 0.00 and tobserved 3.755 , while ttable is 1.6756. because Sig. is less than 0.05 and tobserved is less than ttable too, as the consequence $\mathrm{H}_{0}$ is rejected which means there is a significant effect of independent variable: $\mathrm{X}_{2}$ (grammar mastery) towards the dependent variable Y (student's reading comprehension).

Grammar as the rules that show how words are combined, arranged, or changed to show certain kinds of meaning. Grammar is the study of rules that are claimed to tell the students what he should and should not say in order to speak language of the social educated class. It is a set of rules by which people speak and write. Without grammar, very little can be conveyed, but without vocabulary nothing can be conveyed. It means that the existence of vocabulary cannot be separated by the existence of a language. In other words, no language exists without vocabulary. Refer to the previous statement, so it can be concluded that vocabulary mastery is someone's proficiency in using words and meaning in English language which frequently come up. Besides, vocabulary is also important in language learning which has to be mastered by students in order to develop language skills, especially in reading that students should have adequate vocabulary so that they can understand above reading materials.

Reading comprehension is defined as the level of understanding comes from the interaction between the words that are written and how they trigger knowledge outside the text. Proficient reading depends on the ability to recognize words quickly and effortlessly. If word recognition is difficult, student uses too much of their processing capacity to read individual words, which interferes with their ability to comprehend what is read. It can be assumed that the higher level of grammar mastery of the student especially correlated to listening aspect, the higher the possibility to achieve the ability in reading domain. Grammar mastery may bring positive and significant effect towards the student's reading comprehension.

\section{CONCLUSION}

Some conclusions of this research can be presented as follows:

1. There are significant effects of vocabulary mastery and grammar mastery altogether towards student's reading comprehension of $\mathrm{X} 1$ grade at state Senior High Schools in West Jakarta. It is proven by the score of Fo $=4,160$ dan Sig. $=0,021<0,05$. It means that the higher the students' vocabulary 
mastery and the higher the student's reading comprehension, or vise versa. This indicates that the vocabulary mastery and grammar mastery are two critical variables to be considered in explaining the increase of student's reading comprehension.

2. There is a significant effect of vocabulary mastery towards student's reading comprehension of $X$ grade at State Senior High School in West Jakarta. That is proved by the score of to $=2,662$ dan Sig. $=$ $0,001<0,05$. This means that the higher student's vocabulary mastery, the higher the student's reading comprehension. Conversely, the lower student's vocabulary mastery, the lower student's reading comprehension. Therefore student's vocabulary mastery is an important variable to consider in predicting the student's reading comprehension.

3. There is a significant effect of grammar mastery towards student's reading comprehension of $\mathrm{X}$ grade at State Senior High School in West Jakarta. That is proved by the score of to $=-0,222$ dan Sig. $=0,082>$ 0,05 . This means that the higher student's grammar mastery, the higher student's reading comprehension. Conversely, the lower student's reading comprehension. Therefore student's grammar mastery is an important variable to consider in predicting the student's reading comprehension.

\section{REFERENCES}

Eastwood, J. (2000). Oxford Practice Grammar. New York: Oxford University Press.

Elfrieda, H., Hiebert, \& Kamil, M. L. (2005). Bringing Research and Practice, Teaching and Learning Vocabulary. New Jersey. 2005.

Hornby, A.S. (1995). Oxford Advance Learner Dictionary of Current English. Britain: Oxford University.

Sudjana. (1996). Metode Statistika. Bandung: Tarsito.

Thornburry, S. (2002). How to Teach Vocabulary. Pearson Education Limited: England. 